\title{
BAGAIMANA FUNGSI KEPALA SEKOLAH DAN KOMUNIKASI INTERPERSONAL GURU TERHADAP MUTU PELAYANAN PENDIDIKAN?
}

\author{
Tasrikhah
}

SD Negeri Pabean Udik 1 Indramayu Jawa Barat, tasrikhah2461966@gmail.com

Citation : Tasrikhah. (2020). Bagaimana Fungsi Kepala Sekolah dan komunikasi Interpersonal Guru Terhadap MutuPelayanan Pendidikan?. Edum Journal, 3(2), 131 - 146.

\begin{abstract}
Kondisi saat ini, pendidikan adalah sebuah pelayanan. Untuk dapat memuaskan penggunanya maka kualitas layanan pendidikan harus dijaga agar tetap baik. Faktor yang diduga kuat mempengaruhi pelayanan pendidikan adalah fungsi komunikasi interpersonal kepala sekolah dan guru. Mengingat pentingnya layanan pendidikan, penelitian ini berfokus pada fungsi komunikasi interpersonal kepala sekolah dan guru serta pengaruhnya terhadap kualitas layanan pendidikan. Metode yang digunakan adalah metode survei dengan pendekatan kuantitatif kepada 88 guru sekolah dasar negeri. Teknik pengolahan data menggunakan analisis regresi parsial dan berganda. Hasil penelitian menunjukkan bahwa: (1) Terdapat pengaruh yang positif dan signifikan antara pelaksanaan fungsi kepala sekolah terhadap kualitas pelayanan pendidikan (2) Terdapat pengaruh yang positif dan signifikan antara komunikasi interpersonal guru terhadap kualitas pendidikan. pelayanan (3) Terdapat pengaruh yang positif dan signifikan antara pelaksanaan fungsi kepala sekolah dan komunikasi interpersonal guru secara simultan terhadap kualitas pelayanan pendidikan. Berangkat dari kondisi tersebut, penulis mengemukakan, bahwa: kepala sekolah harus berusaha meningkatkan fungsinya sebagai kepala sekolah, terutama yang terkait dengan memimpin, mengelola, dan memotivasi dengan cara yang lebih optimal untuk menggali potensi dirinya. Guru harus berusaha menanamkan kesadaran akan pentingnya menjaga komunikasi interpersonal sehingga dengan pelaksanaan fungsi kepala sekolah yang optimal maka kualitas pelayanan pendidikan akan meningkat dan layanan pendidikan di sekolah dasar negeri lebih baik.
\end{abstract}

\section{Keywords: Fungsi Kepala Sekolah, Komunikasi Interpersonal, Kualitas Layanan}

\section{PENDAHULUAN}

Secara kuantitas pendidikan di Indonesia telah dapat dikatakan sangat maju. Satuan-satuan pendidikan berdiri dan berkembang layaknya jamur di musim penghujan. Pendidikan dasar hingga pendidikan menengah banyak ditemui sekalipun hanya pada tingkat kecamatan. Apalagi jika dihitung secara kewilayahan yang lebih luas. Kemajuan pendidikan di Indonesia secara kuantitas

tidak berbanding lurus dengan kemajuan secara kualitas. Dikatakan demikian, karena masih ditemui beberapa kekurangan dan kelemahan. Misalnya saja, jika dilihat dari segi pemerataan dan akses. Kesenjangannya masih tinggi. Kemudian jika dilihat dari kesesuaian antara kebutuhan keterampilan yang dibutuhkan oleh dunia usaha dan dunia industri, masih belum sinkron dengan output yang dihasilkan oleh lembaga-lembaga pendidikan terkait.

Akhir-akhir ini mmasyarakat tersadarkan bahwa satuan pendidikan merupakan institusi jasa.
Karena hasil dari operasional pendidikan tidak disebut produk, melainkan disebut lulusan atau output. Beranjak dari asumsi seperti itu, terdapat kecenderungan bahwa institusi pendidikan merupakan suatu lembaga jasa. Berbicara mengenai jasa, identik dengan pelayanan. Pelayanan yang bagus adalah pelayanan yang dapat memenuhin harapan konsumennya. Dalam kaitan satuan pendidikan, konsumennya adalah peserta didik dan orang tua peserta didik.

Setiap siswa maupun orangtua orang tuanya akan selalu mengharapkan suatu pelayanan yang baik dari lembaga pendidikan tempat anaknya menimba ilmu. Pelayanan pendidikan yang baik mendorong siswa merasa nyaman mengikuti pendidikan yang selanjutnya dari kenyamanan yang dirasakan menjadi faktor pendorong pula pada semangat belajarnya. Pada gilirannya harapan siswa untuk mencapai prestasi akademik yang tinggi bukan hanya isapan jempol belaka. 
Pelayanan pendidikan termasuk suatu jasa. Jasa tidak bisa diamati secara fisik namun jasa dapat dirasakan, dan jasa pelayanan pendidikan yang baik dan profesional akan menjawab seberapa jauh kepuasan dapat diraih dan dirasakan oleh peserta didiknya. Di dalam pelayanan jasa pendidikan dimensi yang sangat berkaitan adalah dimensi kurikulum, sumber daya manusia yaitu pendidik dan tenaga kependidikan serta fasilitas atau sarana dan prasarana yang ada.

Kelengkapan peralatan dan fasilitas penunjang pada lembaga pendidikan dibarengi dengan pelayanan yang profesional dapat mendorong peserta didik lebih semangat dalam mengikuti proses pembelajaran yang pada gilirannya kualitas output akan meningkat dari waktu ke waktu. "Kualitas terdiri dan sejumlah keistimewaan produk, baik keistimewaan langsung maupun keistimewaan aktraktif yang memenuhi keinginan pelanggan dan dengan demikian memberikan kepuasan atas penggunaan produk itu. Kualitas terdiri dari segala sesuatu yang bebas dari kekurangan atau kerusakan" (Gaspersz, 2003:5). "Kualitas pada dasarnya dapat berupa kemampuan, barang, dan pelayanan, kualitas pendidikan dapat menunjuk kepada kualitas proses dan kualitas hasil (produk). Namun Demikian kualitas pendidikan di Indonesia masih rendah (Utami, 2019). Suatu pendidikan dapat bermutu dari segi proses (yang sudah barang tentu amat dipengaruhi kualitas masukannya) jika proses belajar mengajar berlangsung secara efektif, dan, peserta didik mengalami proses pembelajaran yang bermakna (meaningful learning) dan juga memperoleh pengetahuan yang berguna baik bagi dirinya maupun bagi orang lain (functional knowledge) yang ditunjang secara wajar oleh sumber daya" (Sartika, 2002:8).

Kondisi pada tataran empirik, pelayanan pendidikan belum sepenuhnya memenuhi harapan. Menelaahan pengalamam penulis selama bekerja lebih dari sepuluh tahun pada satuan pendidikan dasar masih dirasakan adanya kendala, seperti: (1) Pelaksanaan pelayanan praktis yang sifatnya berwujud tidak terdukung oleh kelengkapan perangkat lunak dan perangkat keras yang memadai, sehingga pada saat diperlukan harus mencari-cari terlebih dahulu. Terdapat fenomena instrumen untuk kelancaran pelayanan berupa formulir-formulir yang kurang lengkap persediaannya. (2) Kehandalan produk pelayanan masih menimbulkan keraguan bagi keyakinan konsumen dalam menerima produk layanan.
Misalnya apabila ada yang ingin ditanyakan kepada pihak sekolah apakah akan mendapat respons yang positif? (3) Beberapa unsur pelayanan masih terlihat gejala kurang tanggap. Kurang peka terhadap apa yang diinginkan oleh konsumennya. Seyogyanya setiap tahun ada perbaikan pelayanan sesuai dengan keinginan dan harapan konsumen. Fenomena yang mengemuka, pihak sekolah kurang memperhatikan keinginan atau harapan konsumen dimaksud. (4) Terlihat gejala melemahnya penjaminan kualitas atas produk yang dihasilkan sehingga konsumen kurang yakin terhadap kualitas produk/jasa pendidikan. (5) Adanya fenomena para petugas pelayanan kurang memperhatikan perasaan konsumen saat menggunakan produk/jasa pendidikan. Sepertinya minim perasaan empati dari para petugas pelayanan. Siswa yang membutuhkan pelayanan akademik harus berulang kali datang karena petugas sedang mengerjakan pekerjaan lain. Tidak menanyakan dulu keperluan siswa yang sebenarnya hanya membutuhkan sedikit waktu.

Di atas telah dikemukakan bahwa terdapat beberapa faktor yang mempengaruhi kualitas pelayanan pendidikan, yaitu sumber daya manusia atau guru dan tenaga kependidikan lainnya serta kelengkapan sarana dan prasarana pendidikan. Selain itu, terdapat faktor lain yang dianggap signifikan mempengaruhi kualitas pelayanan pendidikan. Peran dan fungsi kepala sekolah dalam memimpin satuan pendidikan turut mempengaruhi kualitas pelayanan pendidikan. Bagaimanapun, pada satuan pendidikan kepala sekolah merupakan pemimpin, sebagai pengelola, sebagai pengawas, sebagai pendidik bahkan kepala sekolah adalah orang yang harus dapat memotivasi guru dan tenaga kependidikan lainya dalam bekerja dan berprestasi.

Faktor lainnya yang tidak kalah penting dibandingkan faktor yang telah disebutkan, yaitu faktor komunikasi. Faktor komunikasi antar pribadi atau komunikasi interpersonal diduga kuat mempengaruhi kualitas pelayanan pendidikan. Bagaimana kepentingan dan permasalahan bisa disampaikan dan bagaimana materi ajar bisa disampaikan dengan baik apabila lemah dalam mengomunkasikannya. Beberapa hal penting yang membutuhkan kemampuan komunikasi interpersonal dalam kegiatan pendidikan, menyangkut bagaimana menginformasikan sesuatu, meyakinkan seseorang, memotivasi bahkan menghibur orang lain. 
Standar mutu sesungguhnya diukur dengan mutu produksi sesuai kriteria dengan spesifikasi, cocok dengan tujuan pembuatan dan penggunaan, tanpa cacat (zero defect), dan selalu baik sejak awal (right first time and every time). Mutu dalam persepsi diukur dengan kepuasan pelanggan atau pengguna, meningkatnya minat, harapan dan kepuasan pelanggan (Zazin, 2011:63). Kualitas atau mutu memiliki elemen-elemen sebagai berikut: Pertama, meliputi usaha memenuhi atau melebihi harapan pelanggan. Kedua, mencakup produk, jasa, manusia, proses, dan lingkungan. Ketiga, merupakan kondisi yang selalu berubah. Pendidikan itu adalah jasa atau pelayanan (service) dan bukan produksi barang. Satu-satunya indikator kinerja jasa pelayanan adalah kepuasan pelanggan, kinerja kualitas pendidikan dapat diukur dari tingkat kepuasan pelanggan (Nurkolis, 2008:68-70).

Terdapat tiga hubungan untuk mendefinisikan kualitas, yakni: (1) $A n$ understanding of its customers needs; (2) A differentiated market position that Is articulated dearly and consistenly; (3) A vision or mission statement that captures the essence of exactly how the organization serves customers" (Friedman, 1991:5). Sehubungan dengan pemberian pelayanan yang berkualitas, ada tiga kunci memberikan layanan pelanggan yang unggul. Pertama, kemampuan memahami kebutuhan dan keinginan pelanggan. Termasuk di dalamnya memahami tipe-tipe pelanggan. Kedua, pengembangan database yang lebih akurat daripada pesaing (mencakup data kebutuhan dan keinginan setiap segmen pelanggan dan perubahan kondisi persaingan). Ketiga, pemanfaatan informasi-informasi yang diperoleh dari riset pasar dalam suatu kerangka strategik" (Tjiptono, 2001:128).

Pemerintah Indonesia telah menetapkan tentang keharusan adanya jaminan atas mutu pendidikan yang dihasilkan melalui kebijakan Akreditasi Sekolah (Depdiknas, 2004:02) yaitu, bahwa yang dimaksud dengan mutu pelayanan pendidikan adalah: "Jaminan bahwa proses penyelenggaraan pendidikan di sekolah sesuai dengan yang seharusnya terjadi dan sesuai pula dengan yang diharapkan. Agar mutu pendidikan itu sesuai dengan apa yang seharusnya dan apa yang diharapkan yang dijadikan pagu (benchmark)."

Parasuraman menyederhanakan dimensi untuk mengukur kualitas pelayanan secara lebih logis, yaitu: (1) dimensi berwujud (tangibles), untuk mengukur penampilan fasilitas fisik, peralatan, karyawan dan sarana komunikasi; (2) dimensi keandalan (reliability), untuk mengukur kemampuan perusahaan dalam memberikan jasa yang tepat dan dapat diandalkan; (3) dimensi daya tanggap (responsivenessss), menunjukan kesediaan untuk membantu dan memberikan pelayanan kepada pelanggan dengan cepat; (4) dimensi jaminan (assurance), untuk mengukur kemampuan dan keramahan karyawan serta sifat dapat dipercaya; dan (5) dimensi empati (emphaty), untuk mengukur pemahaman karyawan terhadap kebutuhan pelanggan serta perhatian yang diberikan oleh karyawan (Shahin, 2009).

"Kepala sekolah dapat didefinisikan sebagai seorang tenaga fungsional guru yang diberi tugas untuk memimpin suatu sekolah dimana diselenggarakan proses belajar mengajar atau tempat dimana terjadi interaksi antara guru yang memberi pelajaran dan murid yang menerima pelajaran" (Wahjosumidjo, 2002: 83). Kepala sekolah sebagai pimpinan memiliki tanggung jawab mewujudkan visi, misi dan tujuan sekolah (Nai, K., dan Wijayanti, W, 2018). Mengenai fungsi kepala sekolah dapat diartikan bahwa agar para bawahan dengan penuh kemauan serta sesuai dengan kemampuan secara maksimal berhasil mencapai tujuan organisasi, kepala sekolah harus mampu membujuk dan meyakinkan bawahannya.

Dalam paradigma baru manajemen pendidikan, Mulyasa (2004:98) menyimpulkan bahwa "kepala sekolah minimal harus mampu berfungsi sebagai edukator, manajer, advisor, supervisor, leader, inovator dan motivator (EMAS LIM)", yang secara garis besar dapat dijelaskan sebagai berikut: (1) Sebagai pendidik (edukator). Kepala sekolah sebagai edukator memiliki arti kepala sekolah yang menunjukkan komitmen tinggi dan fokus terhadap pengembangan kurikulum dan proses pembelajaran di sekolahnya tentu saja akan sangat memperhatikan tingkat kompetensi yang dimiliki gurunya sehingga proses pembelajaran yang berlangsung dapat berjalan efektif dan efisien; (2) Sebagai Manajer. Kepala sekolah sebagai manajer memiliki arti dalam mengelola tenaga kependidikan, seyogyanya dapat memfasilitasi dan memberikan kesempatan yang luas kepada para guru untuk dapat melaksanakan kegiatan pengembangan profesi melalui berbagai kegiatan pendidikan dan pelatihan baik di dalam maupun di 
luar sekolah; (3) Sebagai Advisor. Kepala sekolah sebagai advisor, harus mampu memberikan komunikasi dua arah dalam hal pemberian saran dan mengarahkan dalam setiap permasalahan yang dihadapi guru sehingga keberhasilan sekolah dapat tercapai; (4) Sebagai Supervisor. Kepala sekolah sebagai supervisor, mengandung pengertian bahwa sebagai seorang pemimpin sekolah, kepala sekolah perlu melaksanakan kegiatan supervisi secara berkala untuk mengetahui sejauh mana guru mampu melaksanakan pembelajaran. Mulyasa (2004:111) menuliskan bahwa "salah satu tugas kepala sekolah adalah supervisor, yaitu mensupervisi pekerjaan yang dilakukan oleh tenaga kependidikan". keunggulannya dalam melaksanakan pembelajaran. (5) Sebagai Leader. (5) Kepala sekolah sebagai leader, dalam rangka meningkatkan kompetensi guru, harus memiliki kepribadian yang kuat sehingga mampu memberikan teladan dan menerapkan gaya kepemimpinan secara tepat dan fleksibel, disesuaikan dengan kondisi dan kebutuhan yang ada. (6) Sebagai Inovator. Kepala sekolah sebagai inovator, harus memiliki strategi yang tepat untuk menjalin hubungan yang harmonis dengan lingkungan, mencari gagasan baru, mengintegrasikan setiap kegiatan, dan mengambangkan model-model pembelajaran yang inovatif. Kepala sekolah yang profesional tidak saja dituntut untuk melaksanakan berbagai tugasnya disekolah tetapi juga harus mampu menjalin hubungan/kerja sama dengan masyarakat dalam rangka membina pribadi peserta didik secara optimal (Mulyasa, 2004: 187). (7) Sebagai Motivator. Kepala sekolah sebagai motivator, harus memiliki strategi yang tepat untuk memberikan motivasi kepada para guru dalam melakukan berbagai tugas dan fungsinya. (Mulyasa, 2004:98-118). Berdasarkan paparan konsep di atas, maka dimensi dari fungsi kepala sekolah dalam penelitian ini adalah: (1) educator, (2) manager, (3) advisor, (4) supervisor, (5) leader, (6) inovator, dan (7) motivator.

Komunikasi terdiri dari dua bentuk, yaitu "komunikasi verbal dan non verbal. Komunikasi verbal merupakan salah satu bentuk komunikasi yang disampaikan kepada pihak lain melalui tulisan dan lisan" (Purwanto, 1997:2). Sedangkan "komunikasi non verbal merupakan bentuk komunikasi yang paling mendasar dalam komunikasi, seperti ragam, dan bahasa isyarat ekspresi wajah, sandi, simbol-simbol, pakaian sewarna intonasi suara" (Purwanto, 1997:145). Komunikasi merupakan "informasi yang menyebabkan adanya pembagian arti (shared meaning) dan pemahaman yang sama (common understanding) untuk pengirim. dan penerima informasi” (Dunne, 1997:134). Komunikasi memiliki beberapa kegunaan yang sangat penting yaitu untuk 1) menginformasikan sesuatu, 2) meyakinkan seseorang atau mempengaruhi orang lain, 3) memotivasi, 4) menghibur orang lain, 5) mengontrol, 6) berkreasi dan, 7) menghancurkan seseorang. (Benjamin dan McKerrow, 1994:3 dalam Dunne, 1997:134).

Bertitik tolak dari beberapa pengertian dan teori-teori tersebut, intensitas komunikasi antarpersonal adalah berapakah dalam satuan waktu seseorang melakukan/menyampaikan gagasan atau ide kepada penerima atau lawan bicara, yang terjadi dua arah baik dengan individu maupun kelompok, dengan maksud agar pesan atau gagasan yang disampaikan dapat dipahami sesuai dengan isi pesan/gagasan yang dimaksudkan.

Sebagaimana disampaikan di atas bahwa, menurut (Dunne, 1997:134) komunikasi merupakan "informasi yang menyebabkan adanya pembagian arti (shared meaning) dan pemahaman yang sama (common understanding) untuk pengirim. dan penerima informasi." Lebih detailnya menurut (Benjamin dan McKerrow, 1994:3 dalam Dunne, 1997:134) bahwa komunikasi "memiliki beberapa kegunaan yang sangat penting yaitu untuk (1) menginformasikan sesuatu, (2) meyakinkan seseorang atau mempengaruhi orang lain, (3) memotivasi, (4) menghibur orang lain, (5) mengontrol, (6) berkreasi dan, (7) menghancurkan seseorang." Tetapi disesuaikan dengan ranah pendidikan maka dimensi komunikasi dalam penelitian ini tidak menggunakan semua dimensi yang disampaikan Benjamin dan McKerrow. Adapun dimensi yang digunakan hanya meliputi: (1) Menginformasikan sesuatu, (2) Meyakinkan seseorang, (3) Memotivasi, (4) Menghibur orang lain, (5) Mengontrol, dan (6) Berkreasi. (Benjamin dan McKerrow, 1994:3 dalam Dunne, 1997:134)

\section{METODE PENELITIAN}

Penelitian ini dilaksanakan pada Sekolah Dasar (SD) Negeri di Gugus Kudalaut Kecamatan Indramayu Kabupaten Indramayu. Populasi dalam penelitian ini adalah seluruh guru sekolah dasar negeri pada Gugus Kudalaut di Kecamatan 
Indramayu Kabupaten Indramayu. Jumlah partisipan sebanyak 88 orang guru. Teknik pengumpulan data dengan menyebarkan angket. Metode pengumpulan data menggunakan angket akan memudahkan analisis dta pada penelitian ini, hal ini sesuai dengan yang dikemukan oleh Singarimbun dan Effendi (2001), dan Rusidi (2005), dibatasi pada pengertian survey sampel yang bertujuan menguji hipotesis yang telah dirumuskan sebelumnya (testing research). Walaupun uraiannya juga mengandung deskripsi, tetapi sebagai penelitian relational fokusnya terletak pada penjelasan hubungan-hubungan antar variabel. Analisis data menggunakan regresi parsial dan regresi ganda.

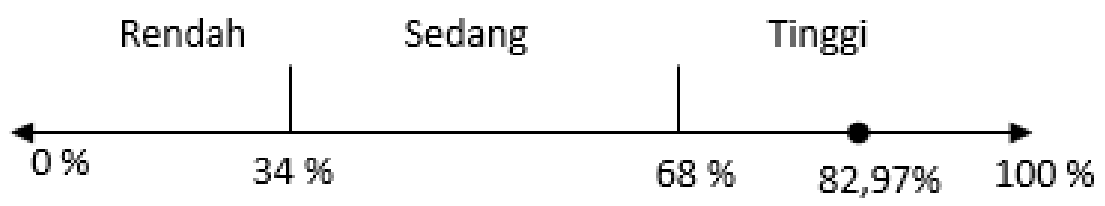

\section{Gambar 1: Kedudukan Implementasi Fungsi Kepala Sekolah dalam Kontinu}

Dari gambar di atas dapat dimaknai bahwa implementasi fungsi kepala sekolah telah mencapai $82,97 \%$ dari kriteria yang ditetapkan, hal ini termasuk pada kategori kriterium tinggi, dengan jarak interval $68 \%-100 \%$, dari persentase tersebut menunjukkan bahwa implementasi fungsi kepala sekolah telah berlangsung sangat bagus.

\section{HASIL PENELITIAN DAN PEMBAHASAN}

Untuk mengetahui

gambaran keberlangsungan implementasi fungsi kepala sekolah, penulis menghitungnya dengan hasil bahwa implementasi fungsi kepala sekolah berada pada kategori kriterium tinggi $(82,97 \%)$ atau berada pada interval 68\% - 100\%. Daerah kriterium implementasi fungsi kepala sekolah sebesar $82,97 \%$ dapat digambarkan sebagai berikut.

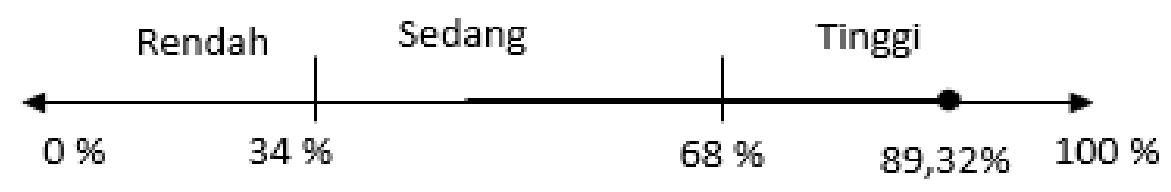

\section{Gambar 2: Kedudukan Komunikasi Interpersonal Guru dalam Kontinu}

Dari gambar di atas dapat dimaknai bahwa komunikasi interpersonal guru telah mencapai $89,32 \%$ dari kriteria yang ditetapkan, hal ini termasuk pada kategori kriterium tinggi, dengan jarak interval $68 \%-100 \%$, dari persentase tersebut menunjukkan bahwa komunikasi interpersonal guru telah berlangsung sangat bagus.
Adapun gambaran kondisi keberlangsungan mutu pelayanan pendidikan terletak pada daerah kriterium tinggi yaitu 81,65 yang berada pada interval $68 \%-100 \%$. Dengan demikian daerah kriterium mutu pelayanan pendidikan sebesar $81,65 \%$ dapat digambarkan sebagai berikut: 


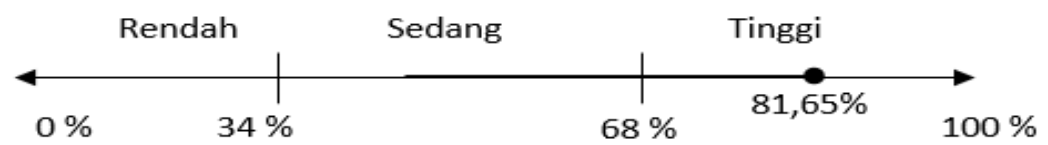

\section{Gambar 3: Kedudukan Variabel Mutu Pelayanan dalam Kontinu}

Dari gambar di atas dapat dimaknai bahwa mutu pelayanan pendidikan telah mencapai $81,65 \%$ dari kriteria yang ditetapkan, hal ini termasuk pada kategori kriterium tinggi, dengan jarak interval $68 \%$ - 100\%. Dari persentase tersebut menunjukkan bahwa mutu pelayanan pendidikan telah berlangsung sangat bagus.

Kecenderungan implementasi fungsi kepala sekolah dapat dilihat dari tiap dimensi, yaitu: Dimensi educator, manager, advisor, supervisor, leader, inovator dan motivator.

Tabel 1: Kecenderungan Kondisi Implementasi Fungsi Kepala Sekolah

\begin{tabular}{|c|c|c|}
\hline Dimensi & Indikator & Skor Rata-rata per Dimensi \\
\hline \multirow{2}{*}{ Educator } & Membimbing guru & \multirow{2}{*}{ ( } \\
\hline & Mengikuti perkembangan IPTEK & \\
\hline \multirow[t]{3}{*}{ Manager } & Menentukan visi, misi dan tujuan sekolah & \multirow[b]{3}{*}{289} \\
\hline & Memimpin berbagai rapat & \\
\hline & Mengambil keputusan & \\
\hline \multirow[t]{2}{*}{ Advisor } & Memberi saran & \multirow[b]{2}{*}{322} \\
\hline & Mengarahkan guru & \\
\hline \multirow[t]{3}{*}{ Supervisor } & Mengarahkan pencapaian target kurikulum & \multirow[b]{3}{*}{318} \\
\hline & Memberikan penilaian berbagai kegiatan & \\
\hline & Mengkoordinasi kegiatan pembelajaran & \\
\hline \multirow[t]{4}{*}{ Leader } & Memiliki sosok panutan bagi para guru & \multirow[b]{4}{*}{337} \\
\hline & Memiliki sosok teladan bagi para guru & \\
\hline & Menciptakan lingkungan kerja yang produktif & \\
\hline & Menjalin hubungan kekeluargaan & \\
\hline \multirow[t]{4}{*}{ Inovator } & Berkreasi & \multirow[b]{4}{*}{236} \\
\hline & Menciptakan daya tarik sekolah & \\
\hline & Amendayagunakan sarana sekolah & \\
\hline & Mendayagunakan prasarana sekolah & \\
\hline \multirow[t]{2}{*}{ Motivator } & Memberi dorongan untuk peningkatan kinerja & \multirow[b]{2}{*}{330} \\
\hline & Memberi dorongan untuk peningkatan SDM & \\
\hline \multicolumn{2}{|l|}{ Skor rata-rata } & $(2.111: 7): 72=4,19$ \\
\hline \multicolumn{2}{|l|}{ Kategori } & Sangat bagus \\
\hline
\end{tabular}

Pada tabel di atas terlihat bahwa semua dimensi implementasi fungsi kepala sekolah sudah tergolong bagus. Untuk lebih mudah memaknainya, dari tabel di atas dapat divisualisasikan sebagai berikut. 


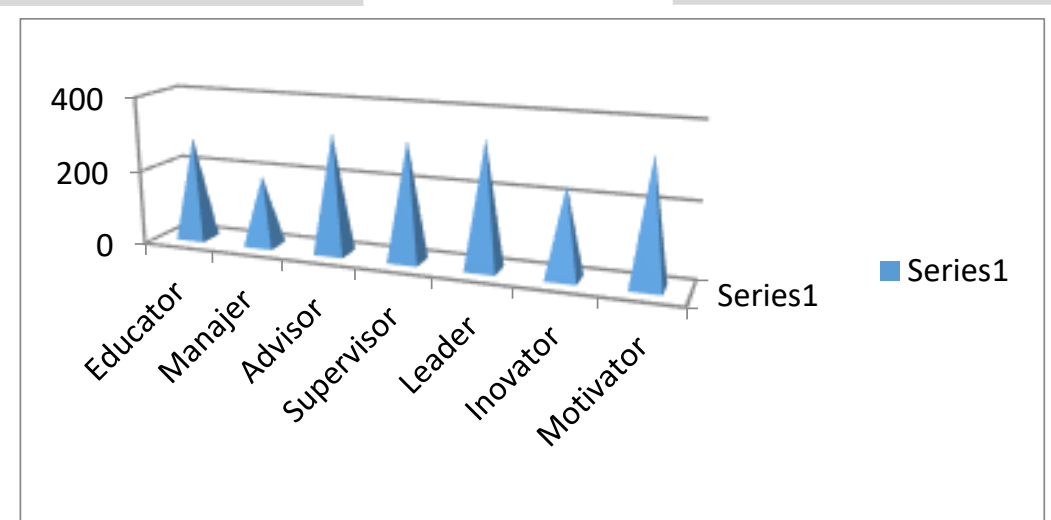

\section{Gambar 4: Kecenderungan Kondisi Implementasi Fungsi Kepala Sekolah}

Berikut dapat dilihat kecenderungan komunikasi interpersonal guru dilihat dari tiap dimensi, yaitu: Dimensi menginformasikan, meyakinkan, memotivasi, menghibur, mengontrol dan berkreasi.

Tabel 2: Kecenderungan Kondisi Komunikasi Interpersonal Guru

\begin{tabular}{|c|c|c|}
\hline Dimensi & Indikator & Skor Rata-rata per Dimensi \\
\hline \multirow[t]{2}{*}{ Menginformasikan } & Menyampaikan pengumuman & \multirow[b]{2}{*}{334} \\
\hline & Menjelaskan peraturan & \\
\hline \multirow[t]{2}{*}{ Meyakinkan } & Diskusi & \multirow[b]{2}{*}{309} \\
\hline & Penjelasan & \\
\hline \multirow[t]{2}{*}{ Memotivasi } & Pujian & \multirow[b]{2}{*}{330} \\
\hline & Menyampaikan apresiasi & \\
\hline \multirow[t]{4}{*}{ Menghibur } & Konsultasi & \multirow[b]{4}{*}{322} \\
\hline & Menerima keluhan & \\
\hline & Memberikan saran & \\
\hline & Memberikan nasihat & \\
\hline \multirow[t]{3}{*}{ Mengontrol } & Kehadiran siswa & \multirow[b]{3}{*}{334} \\
\hline & Pelaksanaan piket & \\
\hline & Tugas pembelajaran & \\
\hline \multirow[t]{2}{*}{ Berkreasi } & Majalah dinding & \multirow[b]{2}{*}{287} \\
\hline & Membentuk kelompok sosial media & \\
\hline \multicolumn{2}{|l|}{ Skor rata-rata } & $(1916: 6): 72=4,44$ \\
\hline \multicolumn{2}{|l|}{ Kategori } & Sangat bagus \\
\hline
\end{tabular}

Pada tabel di atas terlihat bahwa keenam dimensi variabel komunikasi interpersonal guru sudah tergolong sangat bagus. Untuk lebih mudah memaknainya, dari tabel di atas dapat divisualisasikan sebagai berikut. 


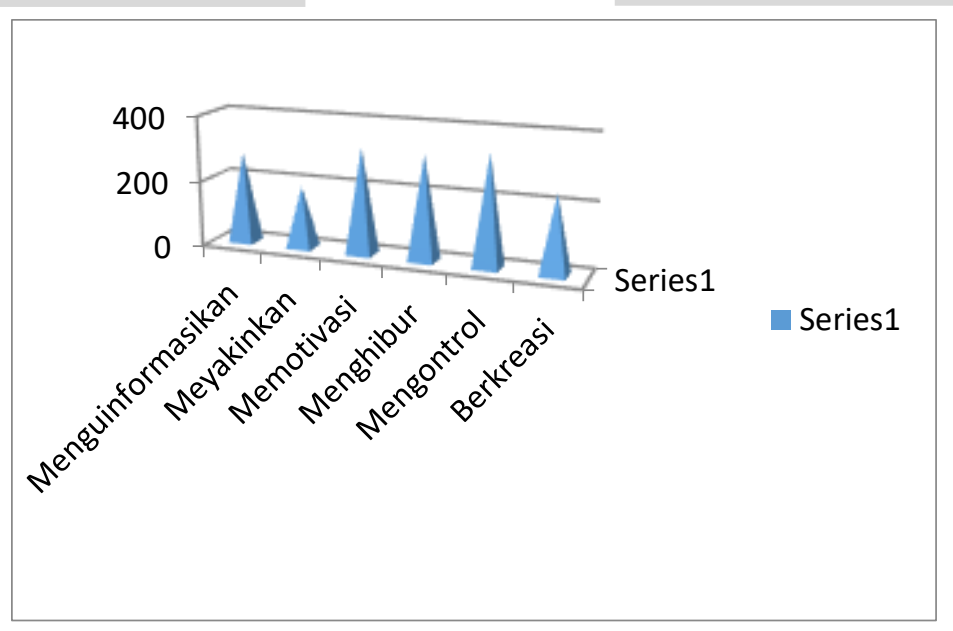

Gambar 5: Kecenderungan Kondisi Komunikasi Interpersonal Guru

Berikut dapat dilihat kecenderungan mutu pelayanan dilihat dari tiap dimensi, yaitu: Dimensi berwujud, kehandalan, tanggap, penjaminan dan empati.

Tabel 3: Kecenderungan Kondisi Dimensi-Dimensi Mutu Pelayanan Pendidikan

\begin{tabular}{|c|c|c|}
\hline Dimensi & Indikator & Skor Rata-rata per Dimensi \\
\hline \multirow[t]{3}{*}{ Berwujud } & Peralatan & \multirow{3}{*}{ 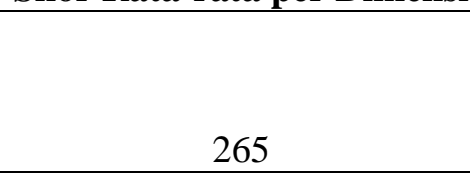 } \\
\hline & Media dan sumber pembelajaran & \\
\hline & Kebersihan lingkungan & \\
\hline \multirow[t]{3}{*}{ Kehandalan } & Kecepatan proses pelayanan & \multirow[b]{3}{*}{259} \\
\hline & Ketepatan pelayanan & \\
\hline & Adil dalam pelayanan & \\
\hline \multirow[t]{3}{*}{ Tanggap } & Kesadaran memberikan pelayanan & \multirow[b]{3}{*}{338} \\
\hline & Tanggap terhadap keinginan siswa & \\
\hline & Menguasai tugas & \\
\hline \multirow[t]{2}{*}{ Penjaminan } & Mampu menjalankan tugas & \multirow[b]{2}{*}{325} \\
\hline & Terampil terhadap pekerjaan & \\
\hline \multirow[t]{4}{*}{ Empati } & Memahami keinginan siswa & \multirow[b]{2}{*}{326} \\
\hline & Merasakan kesulitan siswa & \\
\hline & Skor rata-rata & $(1513: 5): 72=4,20$ \\
\hline & Kategori & Sangat bagus \\
\hline
\end{tabular}

Pada tabel di atas terlihat bahwa kelima dimensi variabel mutu pelayanan sudah sangat bagus. Untuk lebih mudah memaknainya, dari tabel di atas dapat divisualisasikan sebagai berikut. 


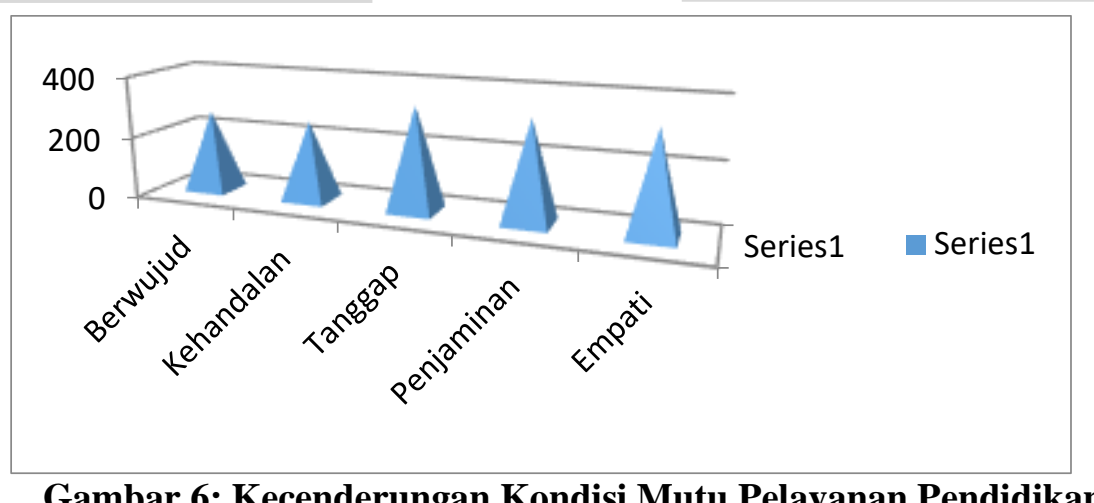

Gambar 6: Kecenderungan Kondisi Mutu Pelayanan Pendidikan

Sebelum dilaksanakan perhitungan, telah dilakukan uji prasyarat, yaitu uji normalitas dan linieritas. Selanjutnya, proses penghitungan dibantu Program SPSS 22 For Windows. Setelah diketahui bahwa data berdistribusi normal dan berpola linier maka langkah selanjutnya dilakukan pengujian untuk menjawab besaran pengaruh implementasi fungsi kepala sekolah dan komunikasi interpersonal guru terhadap mutu pendidikan baik secara parsial maupun nUntuk mengetahui besaran pengaruh implementasi fungsi kepala sekolah secara individual (parsial) terhadap mutu pelayanan pendidikan dapat dilihat dari nilai t pada tabel Coeffiients dibawah ini. Adapun hasil pengujian tersebut adalah sebagai berikut:

\section{Tabel 4: Koefisien Pengaruh Implementasi Fungsi Kepala Sekolah Terhadap Mutu Pelayanan Pendidikan}

\begin{tabular}{|c|c|c|c|c|c|}
\hline \multicolumn{6}{|c|}{ Coefficients $^{\mathbf{a}}$} \\
\hline \multirow[b]{2}{*}{ Model } & \multicolumn{2}{|c|}{$\begin{array}{c}\text { Unstandardized } \\
\text { Coefficients }\end{array}$} & \multirow{2}{*}{$\begin{array}{c}\begin{array}{c}\text { Standardize } \\
\text { d }\end{array} \\
\text { Coefficients } \\
\text { Beta }\end{array}$} & \multirow[b]{2}{*}{$\mathrm{t}$} & \multirow[b]{2}{*}{ Sig. } \\
\hline & $\mathrm{B}$ & Std. Error & & & \\
\hline $1 \quad$ (Constant) & 62,811 & 16,846 & & 3,729 & 001 \\
\hline Fungsi_Kepala_Sekolah_ & ,225 &, 199 & 221 & 1,133 & 268 \\
\hline
\end{tabular}

a. Dependent Variable: Mutu_Pelayanan

Berdasarkan tabel hasil uji $\mathrm{t}$ di atas diperoleh bahwa nilai thitung variabel implementasi fungsi kepala sekolah memiliki nilai sebesar $p$-value $0,001<0,05$ artinya signifikan. Hal tersebut berarti implementasi fungsi kepala sekolah, secara parsial berpengaruh terhadap mutu pelayanan pendidikan.

Persamaan regresi $\mathrm{y}=\mathrm{a} \mathrm{bx}_{1}$ dari hasil perhitungan diperoleh $\mathrm{y}=62.811+0,225 \mathrm{X}_{1}$. Konstanta sebesar 62,811 menyatakan bahwa jika ada kenaikan nilai dari variabel implementasi fungsi kepala sekolah, maka mutu pelayanan pendidikan adalah 62,811 . Koefesien regresi sebesar 0,225 menyatakan bahwa setiap perubahan satu skor atau nilai implementasi fungsi kepala sekolah akan memberikan skor 0,225 .

Dari pengambilan keputusan yaitu dengan membandingkan $F$ hitung dengan nilai F tabel sebagai berikut: jika nilai signifikansi < 0,05 , maka Ho ditolak artinya koefesien regresi signifikan, dan sebaliknya. 
Tabel 5: Signifikansi Pengaruh Implementasi Fungsi Kepala Sekolah terhadap Mutu Pelayanan Pendidikan

\begin{tabular}{|c|c|c|c|c|c|c|}
\hline \multicolumn{7}{|c|}{ ANOVA $^{a}$} \\
\hline \multicolumn{2}{|c|}{ Model } & Sum of Squares & Df & Mean Square & $\mathrm{F}$ & Sig. \\
\hline 1 & Regression & 40,778 & 1 & 40,778 & 1,283 &, $000^{\mathrm{b}}$ \\
\hline & Residual & 794,629 & 25 & 31,785 & & \\
\hline & Total & 835,407 & 26 & & & \\
\hline
\end{tabular}

a. Dependent Variable: Mutu_Pelayanan

b. Predictors: (Constant), Fungsi_Kepala_Sekolah

Berdasarkan tabel hasil uji anova atau $\mathrm{F}$ test didapat $\mathrm{F}_{\text {hitung }}$ sebesar 1,283 dan nilai signifikansi $0,000<0,05$. Dengan demikian $\mathrm{H}_{\mathrm{o}}$ ditolak artinya pengaruh implementasi fungsi kepala sekolah terhadap mutu pelayanan pendidikan adalah signifikan. Menurut Wahjosumidjo (2002:105), bahwa apabila seorang kepala sekolah ingin berhasil menggerakkan para guru, staf dan para siswa berperilaku dalam mencapai tujuan sekolah, oleh karenanya kepala sekolah harus: (1)

Selanjutnya untuk mengetahui besaran pengaruh implementasi fungsi kepala sekolah terhadap mutu pelayanan pendidikan
Menghindari diri dari sikap dan perbuatan yang bersifat memaksa atau bertindak keras terhadap para guru, staf dan para siswa. (2) Sebaliknya kepala sekolah harus mampu melakukan perbuatan yang melahirkan kemauan untuk untuk bekerja dengan penuh semangat dan percaya diri terhadap para guru, staf dan para siswa dengan cara berusaha meyakinkan para guru, staf dan para siswa percaya bahwa apa yang dilakukan dan apa yang dikerjakan adalah benar.

dapat dilihat dari hasil perhitungan koefesien determinasi pada tabel dibawah ini:

\section{Tabel 6: Besaran Pengaruh Implementasi Fungsi Kepala Sekolah terhadap Mutu Pelayanan Pendidikan}

\begin{tabular}{|c|c|r|r|c|}
\hline Model & $\mathrm{R}$ & R Square & $\begin{array}{c}\text { Mdjusted R } \\
\text { Square }\end{array}$ & $\begin{array}{c}\text { Std. Error of the } \\
\text { Estimate }\end{array}$ \\
\hline 1 &, $221^{\mathrm{a}}$ &, 049 &, 011 & 5,638 \\
\hline
\end{tabular}

a. Predictors: (Constant), Fungsi_Kepala_Sekolah

Dari tabel di atas terlihat bahwa $R$ Square sebesar 0,49, hal ini berarti bahwa 4,9 $\%$ mutu pelayanan pendidikan dipengaruhi oleh variabel implementasi fungsi kepala sekolah, sedangkan sisanya $95,1 \%$ dipengaruhi oleh faktor lain yang tidak diteliti.
Untuk mengetahui besaran pengaruh komunikasi interpersonal guru secara individual (parsial) terhadap mutu pelayanan pendidikan dapat dilihat dari nilai t pada tabel Coefficients dibawah ini. Adapun hasil pengujian tersebut adalah sebagai berikut: 
Tabel 7: Koefisien Pengaruh Komunikasi Interpersonal Guru terhadap Mutu Pelayanan Pendidikan

\begin{tabular}{|c|c|c|c|c|c|}
\hline \multicolumn{6}{|c|}{ Coefficients $^{\mathrm{a}}$} \\
\hline \multirow[b]{2}{*}{ Model } & \multicolumn{2}{|c|}{$\begin{array}{c}\text { Unstandardized } \\
\text { Coefficients } \\
\end{array}$} & $\begin{array}{l}\text { Standardized } \\
\text { Coefficients }\end{array}$ & $\mathrm{t}$ & Sig. \\
\hline & B & Std. Error & Beta & & \\
\hline 1 (Constant) & 60,536 & 10,535 & & 5,746 & 000 \\
\hline Komunikasi_Interpersonal Guru & ,236 & ,118 & 234 & 2,010 & 048 \\
\hline
\end{tabular}

a. Dependent Variable: Mutu_Pelayanan

Berdasarkan tabel hasil uji t diperoleh bahwa nilai thitung variabel komunikasi interpersonal guru memiliki nilai sebesar $p$ value $0,000<0,05$ artinya signifikan. Dengan demikian komunikasi interpersonal guru secara parsial berpengaruh terhadap mutu pelayanan pendidikan.

Persamaan regresi $\mathrm{y}=\mathrm{a} \mathrm{bx}_{2}$ dari hasil perhitungan diperoleh $\mathrm{y}=60,536+0,236 \mathrm{X}_{2}$. Konstanta sebesar 60,536 menyatakan bahwa jika ada kenaikan nilai dari variabel komunikasi interpersonal guru, maka mutu pelayanan pendidikan adalah 60,536. Koefesien regresi sebesar 0,236 menyatakan bahwa setiap perubahan satu skor atau komunikasi interpersonal akan memberikan skor 0,236 .

Dari pengambilan keputusan yaitu dengan membandingkan $F$ hitung dengan nilai F tabel sebagai berikut: jika nilai signifikansi $<0,05$, maka Ho ditolak artinya koefesien regresi signifikan, dan sebaliknya

Tabel 8: Signifikansi Pengaruh Komunikasi Interpersonal Guru terhadap Mutu Pelayanan Pendidikan

\begin{tabular}{|rl|r|r|r|c|c|}
\multicolumn{2}{|c|}{ ANOVA $^{\mathrm{a}}$} \\
\hline \multicolumn{1}{|c|}{1} & Sum of Squares & df & Mean Square & F & Sig. \\
\cline { 2 - 7 } & Regression & 164,307 & 1 & 164,307 & 4,038 &, $048^{\mathrm{b}}$ \\
& Residual & 2848,012 & 70 & 40,686 & & \\
& Total & 3012,319 & 71 & & & \\
\hline
\end{tabular}

a. Dependent Variable: Mutu_Pelayanan

b. Predictors: (Constant), Komunikasi_Interpersonal

Berdasarkan tabel hasil uji anova atau $\mathrm{F}$ test didapat $\mathrm{F}_{\text {hitung }}$ sebesar 4.038 dan signifikansi $0,048<0,05$ sehingga $\mathrm{H}_{\mathrm{o}}$ ditolak artinya pengaruh komunikasi interpersonal terhadap mutu pelayanan pendidikan adalah signifikan. Berkenaan dengan komunikasi interpersonal dapat ditinjau dari dua sudut pandang yaitu motivasi untuk menarik hati orang lain dan dari sudut pandang akibat yang ingin diraih. Komunikasi antar personal biasanya dimotivasi oleh faktor kombinasi sebab akibat. Beberapa hal yang harus diperhatikan agar "komunikasi berjalan efektif adalah: keberadaan, mendengarkan, mempertimbangkan ide-ide baru, tenang dan paham sekeliling, berpikir positif, berkomunikasi dengan jelas dan mengatur konflik" (Frion dan Jackson, 1996:110). Setiap orang mempunyai gaya dalam suatu pembicaraan yang dapat dijadikan alat pertimbangan dalam penggunaan bahasa yang efektif, maupun sebagai cerminan pandangan hidup seseorang, untuk dapat mengidentifikasikan perilaku dari gagasan atau ide baru yang ingin disampaikan komunikasi seorang pemimpin akan membenkan dampak psikologis yang besar terhadap situasi dan iklim kerja dari beberapa kelompok kerja yang ada dalam lingkungan organisasi.

Dari pengertian-pengertian yang dikemukakan tersebut jelas bahwa 
komunikasi interpersonal itu benar-benar sangat erat hubungannya dengan seseorang yang melaksanakan tugas sehubungan dengan upaya pencapaian tujuan organisasi. Jadi komunikasi interpersonal guru bersangkutan dengan semua aspek yang berada di luar diri seseorang dalam suatu organisasi yang diamati secara langsung maupun tidak langsung.

Selanjutnya untuk mengetahui besaran pengaruh komunikasi interpersonal terhadap mutu pelayanan pendidikan, dapat dilihat dari hasil perhitungan koefesien determinasi pada tabel dibawah ini:

\section{Tabel 9: Besaran Pengaruh Variabel Komunikasi Interpersonal Guru terhadap Mutu Pelayanan Pendidikan}

Model Summary

\begin{tabular}{|c|r|r|r|r|}
\hline Model & \multicolumn{1}{|c|}{$\mathrm{R}$} & R Square & \multicolumn{1}{c|}{$\begin{array}{c}\text { Adjusted R } \\
\text { Square }\end{array}$} & $\begin{array}{c}\text { Std. Error of the } \\
\text { Estimate }\end{array}$ \\
\hline 1 &, $234^{\mathrm{a}}$ &, 055 &, 041 & 6,379 \\
\hline
\end{tabular}

a. Predictors: (Constant), Komunikasi_Interpersonal_X2

Dari tabel di atas terlihat bahwa $R$ Square sebesar 0,055, hal ini berarti bahwa 5,5 $\%$ mutu pelayanan pendidikan dipengaruhi oleh variabel komunikasi interpersonal guru, sedangkan sisanya $94,5 \%$ dipengaruhi oleh faktor lain yang tidak diteliti. Untuk mengetahui besaran pengaruh implementasi fungsi kepala sekolah kepala sekolah dan komunikasi interpersonal guru secara simultan (ganda) terhadap mutu pelayanan pendidikan dapat dilihat dari nilai t pada tabel Coefficients dibawah ini dengan kriteria pengujian jika tingkat signifikansi lebih kecil dari 0,05 . Adapun hasil pengujian tersebut adalah sebagai berikut:

Tabel 10: Koefisien Pengaruh Implementasi Fungsi Kepala Sekolah dan Komunikasi Interpersonal Guru secara Simultan terhadap Mutu Pelayanan Pendidikan

\section{Coefficients $^{\mathrm{a}}$}

\begin{tabular}{|c|c|c|c|c|c|c|}
\hline \multirow{2}{*}{\multicolumn{2}{|c|}{ Model }} & \multicolumn{2}{|c|}{$\begin{array}{c}\text { Unstandardized } \\
\text { Coefficients }\end{array}$} & \multirow{2}{*}{$\begin{array}{c}\begin{array}{c}\text { Standardized } \\
\text { Coefficients }\end{array} \\
\text { Beta }\end{array}$} & \multirow[b]{2}{*}{$\mathrm{t}$} & \multirow[b]{2}{*}{ Sig. } \\
\hline & & $\mathrm{B}$ & Std. Error & & & \\
\hline & (Constant) & 38,238 & 24,542 & & 1,558 & , 132 \\
\hline & Fungsi_Kepala_Sekolah & ,290 & ,201 & ,285 & 1,441 &, 163 \\
\hline & Komunikasi_Interpersonal & ,215 & 159 & ,268 & 1,357 & , 187 \\
\hline
\end{tabular}

a. Dependent Variable: Mutu_Pelayanan

Berdasarkan tabel hasil uji t diperoleh

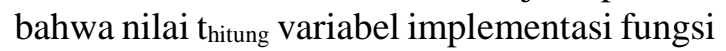
kepala sekolah dan komunikasi interpersonal guru secara bersama-sama (simultan) memiliki nilai sebesar $p$-value $0,000<0,05$ artinya signifikan. Dengan demikian implementasi fungsi kepala sekolah dan komunikasi interpersonal guru secara bersama-sama (simultan) berpengaruh terhadap mutu pelayanan pendidikan.

Untuk mengetahui persamaan regresi dapat dilihat dari tabel di atas. Berdasarkan tabel tersebut menunjukkan persamaan regresi linier ganda:

$$
\widehat{\boldsymbol{Y}}=\underset{\text { Persamaan tersebut menyatakan }}{\mathbf{3 8}, \mathbf{2 3 8}+\mathbf{0}, \mathbf{2 9 0 X 1}+\mathbf{0 , 2 1 5 X 2}}
$$

bahwa setiap penambahan implementasi fungsi kepala sekolah dan komunikasi interpersonal guru sebesar satu maka akan meningkatkan mutu pelayanan pendidikan sebesar 0,290 dan 0,215, artinya setiap peningkatan implementasi fungsi kepemimpinan kepala sekolah dan komunikasi interpersonal guru sebesar satu, 
akan meningkatkan mutu pelayanan pendidikan 0,290 dan 0,215.

Dari pengambilan keputusan yaitu dengan membandingkan $\mathrm{F}$ hitung dengan nilai
F tabel sebagai berikut: Jika nilai signifikansi $<0,05$, maka Ho ditolak artinya koefisien regresi signifikan, dan sebaliknya.

Tabel 11: Signifikansi Pengaruh Variabel Implementasi Fungsi Kepala Sekolah dan Komunikasi Interpersonal Guru secara Simultan terhadap Mutu Pelayanan Pendidikan

\begin{tabular}{|c|c|c|c|c|c|c|}
\hline \multicolumn{7}{|c|}{ ANOVA $^{a}$} \\
\hline \multicolumn{2}{|c|}{ Model } & Sum of Squares & df & Mean Square & $\mathrm{F}$ & Sig. \\
\hline 1 & Regression & 97,420 & 2 & 48,710 & 1,584 &, $006^{\mathrm{b}}$ \\
\hline & Residual & 737,988 & 24 & 30,749 & & \\
\hline & Total & 835,407 & 26 & & & \\
\hline
\end{tabular}

a. Dependent Variable: Mutu_Pelayanan

b. Predictors: (Constant), Komunikasi_Interpersonal_Fungsi_Kepala_Sekolah

Berdasarkan tabel hasil uji anova atau $\mathrm{F}$ test didapat $\mathrm{F}_{\text {hitung }}$ sebesar 1,584 dan signifikansi $0,006<0,05$ sehingga $\mathrm{H}_{\mathrm{o}}$ ditolak artinya pengaruh implementasi fungsi kepala sekolah dan komunikasi interpersonal secara simultan terhadap mutu pelayanan pendidikan adalah signifikan. Seperti dikatakan Wellington (1998:23), organisasi apapun di dunia pasti menyadari sukses mereka amat tergantung pada sejauh mana mereka dapat memuaskan pelanggan mereka, baik pelanggan tadi adalah masyarakat luas, bisnis yang lain atau bahkan bagian lain dalam bisnis mereka sendiri.

besaran

Selanjutnya untuk mengetahui pengaruh implementasi fungsi kepala sekolah dan komunikasi interpersonal guru secara simultan terhadap mutu pelayanan pendidikan dapat dilihat dari hasil perhitungan koefesien determinasi pada tabel dibawah ini:

Tabel: 12: Besaran Pengaruh Variabel Implementasi Fungsi Kepala Sekolah dan Komunikasi Interpersonal Guru Secara Simultan terhadap Mutu Pelayanan Pendidikan

Model Summary

\begin{tabular}{|c|r|r|r|r|}
\hline Model & \multicolumn{1}{|c|}{$\mathrm{R}$} & R Square & \multicolumn{1}{c|}{$\begin{array}{c}\text { Adjusted R } \\
\text { Square }\end{array}$} & $\begin{array}{c}\text { Std. Error of the } \\
\text { Estimate }\end{array}$ \\
\hline 1 &, $341^{\mathrm{a}}$ &, 117 &, 043 & 5,545 \\
\hline
\end{tabular}

a. Predictors: (Constant), Komunikasi_Interpersonal_Guru,

Fungsi_Kepala_Sekolah

Dari tabel di atas terlihat bahwa $R$ Square sebesar 0,117 hal ini berarti bahwa $11,7 \%$ mutu pelayanan pendidikan dipengaruhi oleh variabel implementasi fungsi kepala sekolah dan komunikasi interpersonal secara simultan, sedangkan sisanya 88,3\% dipengaruhi faktor lain yang tidak diteliti. Permasalahan yang ingin dijawab dalam penelitian ini adalah adakah pengaruh implementasi fungsi kepala sekolah terhadap mutu pelayanan pendidikan. Secara empirik, hasil penelitian ini menginformasikan:
(1) terdapat pengaruh positif dan signifikan antara implementasi fungsi kepala sekolah terhadap mutu pelayanan pendidikan, serta (2) besarnya pengaruh implementasi fungsi kepala sekolah terhadap mutu pelayanan pendidikan ditunjukkan oleh hasil penelitian bahwa implementasi fungsi kepala sekolah yang terdiri dari dimensi: (1) Educator; (2) Manager; (3) Advisor; (4) Supervisor; (5) Leader; (6) Inovator; (7) Motivator (Mulyasa, 2004), membawa implikasi yang signifikan terhadap 
mutu pelayanan pendidikan yang meliputi dimensi: (1) Tangibles (berwujud); (2) Reliability (kehandalan); (3) Rresponsiveness (tanggap); (4) Assurance (jaminan); (5) Emphaty (empati) (Parasuraman dalam Shahin, 2009).

Namun demikian mutu pelayanan pendidikan ini tidak hanya dipengaruhi oleh implementasi fungsi kepala sekolah saja, ada faktor lain (epsilon), selain dari komunikasi interpersonal guru, yang juga berpengaruh, yang tidak dikaji dalam penelitian ini. Dengan demikian, hasil penelitian ini mengindikasikan bahwa semakin baik implementasi fungsi kepala sekolah, maka akan diikuti oleh semakin tingginya mutu pelayanan pendidikan. Hal ini dapat diterangkan oleh persamaan regresi $\mathrm{y}=$ $62,811+0,225 \mathrm{X}_{1}$. Dengan persamaan regresi tersebut dapat diinterpretasikan bahwa jika implementasi fungsi kepala sekolah dan mutu pelayanan pendidikan diukur dengan instrumen yang dikembangkan dalam penelitian ini, maka setiap perubahan skor implementasi fungsi kepala sekolah sebesar satu satuan dapat diestimasikan skor mutu pelayanan pendidikan akan berubah 0,225 satuan pada arah yang sama.

Berdasarkan temuan empirik yang menunjukkan adanya pengaruh yang signifikan implementasi fungsi kepala sekolah dengan mutu pelayanan pendidikan, maka hasil penelitian ini memberikan beberapa informasi, di antaranya: (1) implementasi fungsi kepala sekolah memberikan kontribusi yang berarti terhadap mutu pelayanan pendidikan, (2) salah satu cara untuk meningkatkan mutu pelayanan pendidikan adalah dengan meningkatkan implementasi fungsi kepala sekolah, serta (3) persentase kontribusi implementasi fungsi kepala sekolah terhadap mutu pelayanan pendidikan adalah sebesar 4,9\%, sementara sisanya dipengaruhi oleh variabel lain, selain variabel komunikasi interpersonal, yang tidak dikaji dalam penelitian ini (epsilon).

Permasalahan yang ingin dijawab dalam penelitian ini selanjutnya adalah adakah pengaruh komunikasi interpersonal terhadap mutu pelayanan pendidikan. Secara empirik, hasil penelitian ini menginformasikan: (1) terdapat pengaruh positif dan signifikan antara komunikasi interpersonal terhadap mutu pelayanan pendidikan, serta (2) besarnya kontribusi komunikasi interpersonal terhadap mutu pelayanan pendidikan ditunjukkan oleh hasil penelitian bahwa komunikasi interpersonal yang terdiri dari dimensi: (1) Menginformasikan sesuatu; (2) Meyakinkan seseorang; (3) Memotivasi; (4) Menghibur orang lain; (5) Mengontrol; (6) Berkreasi (Benjamin dan McKerrow, 1994 dalam Dunne, 1997), membawa implikasi yang signifikan terhadap mutu pelayanan pendidikan yang meliputi dimensi: (1) Tangibles (berwujud); (2) Reliability (kehandalan); (3) Rresponsiveness (tanggap); (4) Assurance (jaminan); (5) Emphaty (empati) (Parasuraman dalam Shahin, 2009).

Namun demikian mutu pelayanan pendidikan ini tidak hanya dipengaruhi oleh komunikasi interpersonal guru saja, ada faktor lain (epsilon), selain dari implementasi fungsi kepala sekolah, yang juga berpengaruh, yang tidak dikaji dalam penelitian ini.

Dengan demikian, hasil penelitian ini mengindikasikan bahwa semakin baik komunikasi interpersonal guru, maka akan diikuti oleh semakin tingginya mutu pelayanan pendidikan. Hal ini dapat diterangkan oleh persamaan regresi $y=60,536+0,236 X_{2}$. Dengan persamaan regresi tersebut dapat diinterpretasikan bahwa jika komunikasi interpersonal dan mutu pelayanan pendidikan diukur menggunakan instrumen yang dikembangkan dalam penelitian ini, maka setiap perubahan skor komunikasi interpersonal guru sebesar satu satuan dapat diestimasikan skor mutu pelayanan pendidikan akan berubah 0,236 satuan pada arah yang sama.

Berdasarkan temuan empirik yang menunjukkan adanya pengaruh yang signifikan komunikasi interpersonal guru terhadap mutu pelayanan, maka hasil penelitian ini memberikan beberapa informasi, di antaranya: (1) komunikasi interpersonal guru memberikan kontribusi yang berarti terhadap mutu pelayanan pendidikan, (2) salah satu cara untuk meningkatkan mutu pelayanan pendidikan adalah dengan meningkatkan komunikasi interpersonal guru, serta (3) persentase kontribusi komunikasi interpersonal guru terhadap mutu pelayanan pendidikan adalah sebesar $5,5 \%$, sementara sisanya dipengaruhi oleh variabel lain, selain variabel implementasi fungsi kepala sekolah, yang tidak dikaji dalam penelitian ini (epsilon).

Permasalahan terakhir yang ingin dijawab dalam penelitian ini adalah adakah pengaruh implementasi fungsi kepala sekolah, dan komunikasi interpersonal guru secara simultan terhadap mutu pelayanan pendidikan. 
Secara empirik, hasil penelitian ini menginformasikan: (1) terdapat pengaruh positif dan signifikan antara implementasi fungsi kepala sekolah dan komunikasi interpersonal guru secara simultan terhadap mutu pelayanan pendidikan, serta (2) besarnya pengaruh implementasi fungsi kepala sekolah dan komunikasi interpersonal guru terhadap mutu pelayanan pendidikan ditunjukkan oleh hasil penelitian bahwa implementasi fungsi kepala sekolah yang terdiri dari dimensi: (1) Educator; (2) Manager; (3) Advisor; (4) Supervisor; (5) Leader; (6) Inovator; (7) Motivator (Mulyasa, 2004), serta komunikasi interpersonal guru yang terdiri atas dimensi: (1) Menginformasikan sesuatu; (2) Meyakinkan seseorang; (3) Memotivasi; (4) Menghibur orang lain; (5) Mengontrol; (6) Berkreasi (Benjamin dan McKerrow, 1994 dalam Dunne, 1997). membawa implikasi yang signifikan terhadap mutu pelayanan pendidikan yang meliputi dimensi: (1) Tangibles (berwujud); (2) Reliability (kehandalan); (3) Rresponsiveness (tanggap); (4) Assurance (jaminan); (5) Emphaty (empati) (Parasuraman dalam Shahin, 2009).

Namun demikian mutu pelayanan pendidikan ini tidak hanya dipengaruhi oleh implementasi fungsi kepala sekolah, dan komunikasi interpersonal guru saja, ada faktor lain (epsilon), yang juga berpengaruh, yang tidak dikaji dalam penelitian ini. Dengan demikian, hasil penelitian ini mengindikasikan bahwa semakin baik implementasi fungsi kepala sekolah, dan semakin bagus komunikasi interpersonal guru, maka akan diikuti oleh semakin tingginya mutu pelayanan pendidikan. Hal ini dapat diterangkan oleh persamaan regresi: $\widehat{Y}=38,238+0,290 X 1+0,215 X 2$.

Dengan persamaan regresi tersebut dapat diinterpretasikan bahwa jika implementasi fungsi kepemimpinan kepala sekolah, dan komunikasi interpersonal guru dengan mutu pelayanan pendidikan diukur menggunakan instrumen yang dikembangkan dalam penelitian ini, maka setiap perubahan skor implementasi fungsi kepemimpinan kepala sekolah dan komunikasi interpersonal guru sebesar satu satuan dapat diestimasikan skor mutu pelayanan pendidikan akan berubah 0,290 dan 0,215 satuan pada arah yang sama.

Berdasarkan temuan empirik yang menunjukkan adanya pengaruh yang signifikan implementasi fungsi kepemimpinan kepala sekolah, dan komunikasi interpersonal guru terhadap mutu pelayanan pendidikan, maka hasil penelitian ini memberikan beberapa informasi, di antaranya: (1) implementasi fungsi kepemimpinan kepala sekolah, dan komunikasi interpersonal guru memberikan kontribusi yang berarti terhadap mutu pelayanan pendidikan, (2) salah satu cara untuk meningkatkan mutu pelayanan pendidikan adalah dengan meningkatkan implementasi fungsi kepemimpinan kepala sekolah dan komunikasi interpersonal guru. (3) persentase kontribusi yang diberikan oleh implementasi fungsi kepala sekolah dan komunikasi interpersonal guru secara simultan terhadap mutu pelayanan pendidikan adalah sebesar $11,7 \%$, sementara sisanya dipengaruhi oleh variabel lain, yang tidak dikaji dalam penelitian ini (epsilon).

Bertolak dari hasil penelitian di atas, penulis merekomendasi sebagai berikut: (1) Mutu pelayanan pendidikan yang tinggi merupakan salah satu misi yang harus dicapai setiap sekolah, mutu pelayanan pendidikan ini sudah terbukti dipengaruhi oleh implementasi fungsi kepala sekolah dan komunikasi interpersonal guru. Oleh karena itu, kepala sekolah seyogyanya berusaha meningkatkan lagi fungsinya sebagai kepala sekolah terutama yang berkaitan dengan leading, managing dan motivating dengan cara lebih optimal lagi menggali potensi dalam dirinya. Sehingga diharapkan dengan optimalnya implementasi fungsi kepala sekolah, maka mutu pelayanan pendidikan akan meningkat. (2) Setiap guru harus mengembangkan dirinya dengan menggali potensi dalam dirinya, mengikuti berbagai pelatihan untuk guru dan melanjutkan pendidikan kejenjang pendidikan yang lebih tinggi. Selain itu dalam setiap diri guru harus berusaha menanamkan kesadaran akan pentingnya memelihara komunikasi interpersonal misalnya dengan optimalisasi komunikasi media sosial seperti membentuk group dalam Whatsapp, maka pelayanan pendidikan akan lebih baik serta terpeliharanya silaturahim. 


\section{KESIMPULAN}

Kesimpulan penelitian ini adalah sebagai berikut: (1) Mutu pelayanan pendidikan tinggi merupakan salah satu misi yang harus dicapai oleh setiap sekolah, mutu pelayanan pendidikan terbukti sangat dipengaruhi oleh penyelenggaraan pendidikan kepala sekolah. fungsi dan komunikasi interpersonal guru. Oleh karena itu, kepala sekolah harus berusaha meningkatkan fungsinya sebagai kepala sekolah, terutama yang terkait dengan memimpin, mengelola, dan memotivasi dengan cara yang lebih optimal untuk menggali potensi dirinya. Sehingga diharapkan dengan pelaksanaan fungsi kepala sekolah yang optimal maka kualitas pelayanan pendidikan

\section{DAFTAR PUSTAKA}

Arikunto, Suharsimi. (2007). Manajemen Penelitian. Jakarta: Rineka Cipta.

Dunne, Patrick (1997), Running Board Meetings: Tips and Techniques for Getting the Best from Them, London: British Library Cataloguing in Publ. Data.

Friedman, Margaret L. (1991) Marketing For The Service Industries. New York: American Management Association.

Gaspersz, Vincent. (2003), Total Quality Management. Jakarta: Gramedia.

Mulyasa, E. (2004). Menjadi Kepala Sekolah Profesional. Bandung: PT. Remaja Rosdakarya.

Nai, K., dan Wijayanti, W. (2018).Pelaksanaan Tugas Dan Fungsi Kepala Sekolah Pendidikan Menengah Negeri. Jurnal Akuntabilitas Manajemen Pendidikan. Vol. 6, No. 2, 183-192.

Nurkolis. (2006). Manajemen Berbasis Sekolah: Teori, Model, dan Aplikasi. Jakarta: Grasindo.

Purwanto, Djoko, (1997), Komunikasi Bisnis, Jakarta: Erlangga, 1997.

Rusidi. (2005). Metode dan Teknik Penelitian ilmu-ilmu sosial. Bandung: Program Pascasarjana Unpad.

Sartika, Ikke Dewi. (2002). Quality Service in Education, Edisi Khusus untuk Kalangan Mahasiswa, Bandung: Yayasan Potensia. Shahin, A. (2009). Servqual and Model of Service Quality Gaps: A Framework for Determining and Prioritizing Critical Factors in Delivering Quality Services. Department of Management, University akan meningkat. (2) Setiap guru harus mengembangkan dirinya dengan menggali potensi dalam dirinya, mengikuti berbagai pelatihan bagi guru dan melanjutkan pendidikan yang lebih tinggi. Selain itu, dalam setiap diri guru harus berusaha menanamkan kesadaran akan pentingnya menjaga komunikasi interpersonal, misalnya dengan mengoptimalkan komunikasi media sosial seperti membentuk kelompok di Whatsapp, maka layanan pendidikan di sekolah dasar negeri lebih baik dan penjagaan silaturahmi akan semakin baik.

of Isfahan, Iran, (Online), (http://www.proserv.nu, diakses 4 Oktober 2010).

Singarimbun, M. dan Sofyan Effendi, (2001), Metode Penelitian Survei. Jakarta: Pustaka LP3ES Indonesia.

Utami, Sri. (2019). Meningkatkan Mutu Pendidikan Indonesia Melalui Peningkatan Kualitas Personal, Profesional, Dan Strategi Rekrutmen Guru. Prosiding Seminar Nasional Pendidikan FKIP Universitas Sultan Ageng Tirtayasa. Vol. 2, No.1, hal. 518527

Wahjosumidjo. (2002), Kepemimpinan Kepala Sekolah: Tinjauan Teoritik dan Permasalahannya. Jakarta: RahaGrafubdi Persada.

Zazin, Nur. (2011), Gerakan Menata Mutu Pendidikan: Teori dan Aplikasi, Jogjakarta: Ar-Ruzz Media.

Zeitharml, V. A. (1990). Delivering Service Quality: Balancing Customer Perceptions and Expectations. New York: The Free Press.

Undang-undang Republik Indonesia Nomor 14 Tahun 2005 tentang Guru dan Dosen.

Undang-Undang RI Nomor 20 Tahun 2003 tentang Sistem Pendidikan Nasional. Jakarta: Depdiknas.P a g e | 146

Depdiknas. (2004). Manajemen Mutu Berbasais Sekolah, Jakarta: Dirjen Dikdasmen. 